\title{
Online Appendix: Does voluntary disclosure matter when nonprofit organizations violate stakeholder trust?
}

\author{
Jurgen Willems \\ Universität Hamburg \\ Lewis Faulk \\ American University
}

\section{Supplementary materials to:}

Willems, J., \& Faulk, L. (2019). Does voluntary disclosure matter when nonprofit organizations violate stakeholder trust? Journal of Behavioral Public Administration, 2(1). http:/ /journal-

bpa.org/index.php/jbpa/article/view/45

\section{Overview}

In this Online Appendix we report additional materials, descriptive statistics, and complementary analyses to our main studies (Willems \& Faulk, 2019a). In the section Experimental vignettes, the vignettes for all three experiments are reported, along with the treatment group names. In the section Distribution of donation amount we visually document the distribution of the dependent variable in all three experiments and compare this distribution across the three experiments and the treatment groups. This gives an insight in how the crisis situation and the availability of disclosure information influence the distribution of donation intention. In the final section - Additional materials for Experiment 3 - we report on the one hand our detailed considerations for the sample size calculation (based on Experiments 1 and 2), and on the other hand the complementary post-hoc analyses for Experiment 3.

Data and research protocol, in R (R Core Team 2018), are publicly available at https://osf.io/wqzsa/ (Willems \& Faulk, 2019b). This study is part of a larger project on reputation management, funded by the German Research Foundation (Willems \& Waldner, 2019). 


\section{Experimental vignettes (all three experiments)}

In Table 7, the nine different vignettes are given. All vignettes were by the instruction "Please read the description below of the environmental nonprofit EarthLove."

\section{Table 7}

Vignettes for Experiments 1, 2 and 3

\begin{tabular}{|c|c|}
\hline Description & Vignette \\
\hline $\begin{array}{l}\text { Base case } \\
\text { (Experiments } \\
1,2 \& 3)\end{array}$ & $\begin{array}{l}\text { EarthLove is a nonprofit that aims at improving the environment in and around } \\
\text { large cities (both in Western and Third World countries). EarthLove uses the } \\
\text { donations that they receive to invest in small social enterprises that are strongly } \\
\text { embedded in local communities. }\end{array}$ \\
\hline $\begin{array}{l}\text { Low crisis, } \\
\text { no disclosure } \\
\text { info } \\
\text { (Experiments } \\
2 \text { \& 3) }\end{array}$ & $\begin{array}{l}\text { EarthLove is a nonprofit that aims at improving the environment in and around } \\
\text { large cities (both in Western and Third World countries). EarthLove uses the } \\
\text { donations that they receive to invest in small social enterprises that are strongly } \\
\text { embedded in local communities. } \\
\text { Last week, EarthLove dismissed an employee for using donated funds for } \\
\text { personal trips and purchases over the last year. } \\
\text { EarthLove followed up by announcing that this case will be used to evaluate } \\
\text { internal procedures, and that steps will be taken to increase transparency towards } \\
\text { donors in the future. }\end{array}$ \\
\hline $\begin{array}{l}\text { Low crisis, } \\
\text { voluntary } \\
\text { disclosure } \\
\text { (Experiments } \\
2 \text { \& 3) }\end{array}$ & $\begin{array}{l}\text { EarthLove is a nonprofit that aims at improving the environment in and around } \\
\text { large cities (both in Western and Third World countries). EarthLove uses the } \\
\text { donations that they receive to invest in small social enterprises that are strongly } \\
\text { embedded in local communities. } \\
\text { Last week, EarthLove used its website and mailing lists to voluntarily } \\
\text { disclose that EarthLove dismissed an employee for using donated funds for } \\
\text { personal trips and purchases over the last year. } \\
\text { EarthLove followed up by announcing that this case will be used to evaluate } \\
\text { internal procedures, and that steps will be taken to increase transparency towards } \\
\text { donors in the future. }\end{array}$ \\
\hline $\begin{array}{l}\text { Low crisis, } \\
\text { third-party } \\
\text { disclosure } \\
\text { (Experiments } \\
2 \text { \& 3) }\end{array}$ & $\begin{array}{l}\text { EarthLove is a nonprofit that aims at improving the environment in and around } \\
\text { large cities (both in Western and Third World countries). EarthLove uses the } \\
\text { donations that they receive to invest in small social enterprises that are strongly } \\
\text { embedded in local communities. } \\
\text { Last week, it was revealed in an investigative report by a large national } \\
\text { newspaper that EarthLove dismissed an employee for using donated funds } \\
\text { for personal trips and purchases over the last year. }\end{array}$ \\
\hline
\end{tabular}




\begin{tabular}{|c|c|}
\hline & $\begin{array}{l}\text { EarthLove followed up by announcing that this case will be used to evaluate } \\
\text { internal procedures, and that steps will be taken to increase transparency towards } \\
\text { donors in the future. }\end{array}$ \\
\hline $\begin{array}{l}\text { Low crisis, } \\
\text { voluntary } \\
\text { and third- } \\
\text { party } \\
\text { disclosure } \\
\text { (Experiments } \\
2 \& 3 \text { ) }\end{array}$ & $\begin{array}{l}\text { EarthLove is a nonprofit that aims at improving the environment in and around } \\
\text { large cities (both in Western and Third World countries). EarthLove uses the } \\
\text { donations that they receive to invest in small social enterprises that are strongly } \\
\text { embedded in local communities. } \\
\text { Last week, on the same day it was revealed in an investigative report by a } \\
\text { large national newspaper, EarthLove used its website and mailing lists to } \\
\text { voluntarily disclose that EarthLove dismissed an employee for using } \\
\text { donated funds for personal trips and purchases over the last year. } \\
\text { EarthLove followed up by announcing that this case will be used to evaluate } \\
\text { internal procedures, and that steps will be taken to increase transparency towards } \\
\text { donors in the future. }\end{array}$ \\
\hline $\begin{array}{l}\text { High crisis, } \\
\text { no disclosure } \\
\text { info } \\
\text { (Experiments } \\
1 \text { \& 3) }\end{array}$ & $\begin{array}{l}\text { EarthLove is a nonprofit that aims at improving the environment in and around } \\
\text { large cities (both in Western and Third World countries). EarthLove uses the } \\
\text { donations that they receive to invest in small social enterprises that are strongly } \\
\text { embedded in local communities. } \\
\text { Last week, EarthLove dismissed three of its board members in the last year } \\
\text { for stealing money from the organization's funds. } \\
\text { EarthLove followed up by announcing that this case will be used to evaluate } \\
\text { internal procedures, and that steps will be taken to increase transparency towards } \\
\text { donors in the future. }\end{array}$ \\
\hline $\begin{array}{l}\text { High crisis, } \\
\text { voluntary } \\
\text { disclosure } \\
\text { (Experiments } \\
1 \text { \& 3) }\end{array}$ & $\begin{array}{l}\text { EarthLove is a nonprofit that aims at improving the environment in and around } \\
\text { large cities (both in Western and Third World countries). EarthLove uses the } \\
\text { donations that they receive to invest in small social enterprises that are strongly } \\
\text { embedded in local communities. } \\
\text { Last week, EarthLove used its website and mailing lists to voluntarily } \\
\text { disclose that EarthLove dismissed three of its board members in the last } \\
\text { year for stealing money from the organization's funds. } \\
\text { EarthLove followed up by announcing that this case will be used to evaluate } \\
\text { internal procedures, and that steps will be taken to increase transparency towards } \\
\text { donors in the future. }\end{array}$ \\
\hline $\begin{array}{l}\text { High crisis, } \\
\text { third-party } \\
\text { disclosure } \\
\text { (Experiments } \\
1 \& 3 \text { ) }\end{array}$ & $\begin{array}{l}\text { EarthLove is a nonprofit that aims at improving the environment in and around } \\
\text { large cities (both in Western and Third World countries). EarthLove uses the } \\
\text { donations that they receive to invest in small social enterprises that are strongly } \\
\text { embedded in local communities. }\end{array}$ \\
\hline
\end{tabular}




\begin{tabular}{|l|l|}
\hline & $\begin{array}{l}\text { Last week, it was revealed in an investigative report by a large national } \\
\text { newspaper that EarthLove dismissed three of its board members in the last } \\
\text { year for stealing money from the organization's funds. } \\
\text { EarthLove followed up by announcing that this case will be used to evaluate } \\
\text { internal procedures, and that steps will be taken to increase transparency towards } \\
\text { donors in the future. }\end{array}$ \\
\hline $\begin{array}{l}\text { High crisis, } \\
\text { voluntary } \\
\text { party third- } \\
\text { disclosure } \\
(\text { Experiments } \\
1 \text { \& 3) }\end{array}$ & $\begin{array}{l}\text { EarthLove is a nonprofit that aims at improving the environment in and around } \\
\text { large cities (both in Western and Third World countries). EarthLove uses the } \\
\text { donations that they receive to invest in small social enterprises that are strongly } \\
\text { embedded in local communities. } \\
\text { Last week, on the same day it was revealed in an investigative report by a } \\
\text { large national newspaper, EarthLove used its website and mailing lists to } \\
\text { voluntarily disclose that EarthLove dismissed three of its board members in } \\
\text { the last year for stealing money from the organization's funds. }\end{array}$ \\
& $\begin{array}{l}\text { EarthLove followed up by announcing that this case will be used to evaluate } \\
\text { internal procedures, and that steps will be taken to increase transparency towards } \\
\text { donors in the future. }\end{array}$
\end{tabular}

\section{Distribution of donation amount (all three experiments)}

In Figures 5 and 6, we give an overview of the non-normal distributions of the dependent variable in all three experiments, and we make a distinction between those respondents that did not receive the crisis information and those who did. As a result, the differences between the green and the blue areas show the distribution change as a result of the respective crisis descriptions in Experiments 1 and 2, and for both crisis descriptions combined for Experiment 3. 
Figure 5

Density plots for donation amount for all three experiments ('crisis' versus 'no crisis')
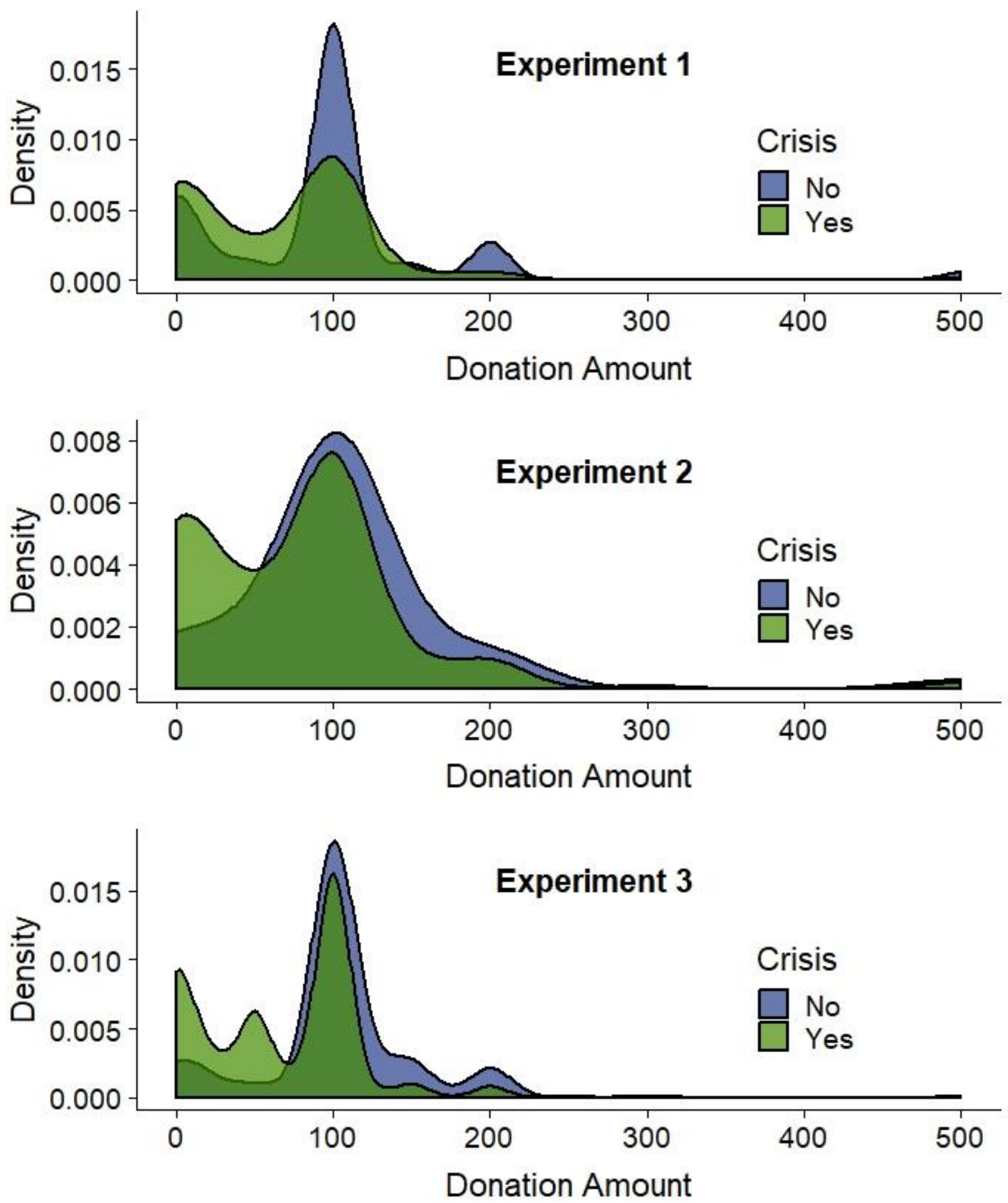
Figure 6

Density plots for donation amount for all three experiments (per treatment group; vertical line between dark and light blue indicates the median)

\section{Experiment 1}

High crisis, no disclosure info

High crisis, voluntary disclosure

High crisis, third-party disclosure

High crisis, voluntary and third-party disclosure

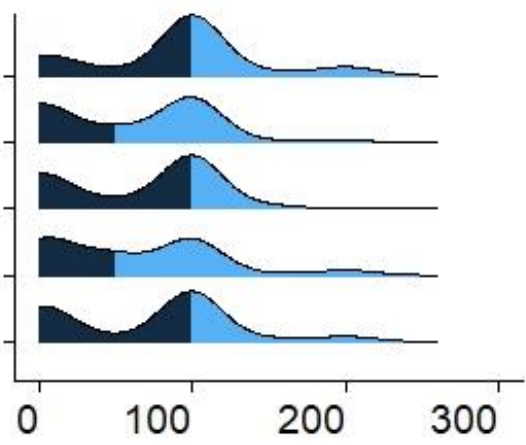

\section{Experiment 2}

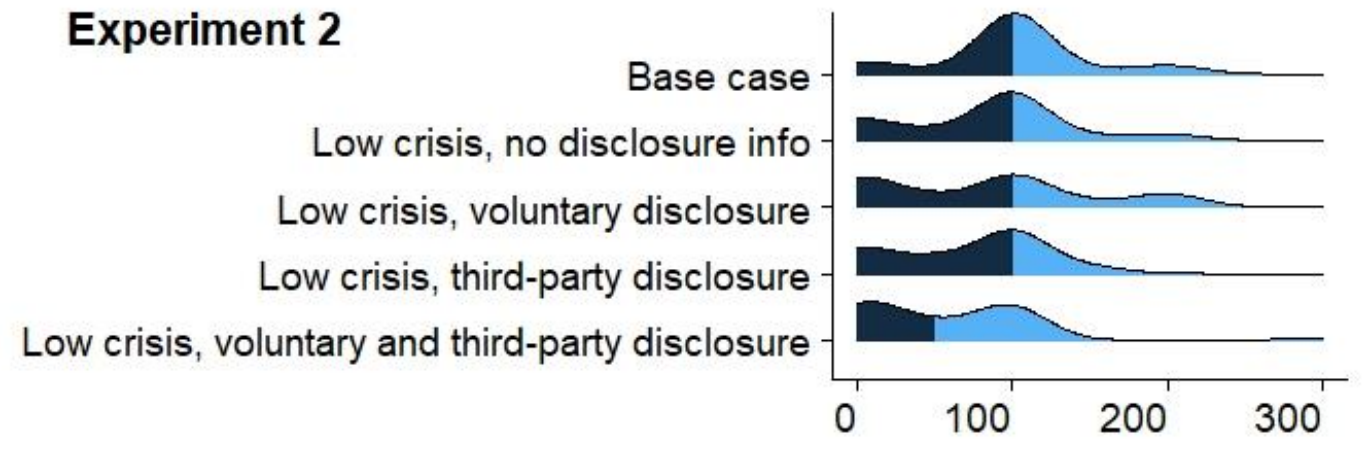

\section{Experiment 3}

Low crisis, no disclosure info

Low crisis, voluntary disclosure

Low crisis, third-party disclosure

Low crisis, voluntary and third-party disclosure

High crisis, no disclosure info

High crisis, voluntary disclosure

High crisis, third-party disclosure

High crisis, voluntary and third-party disclosure

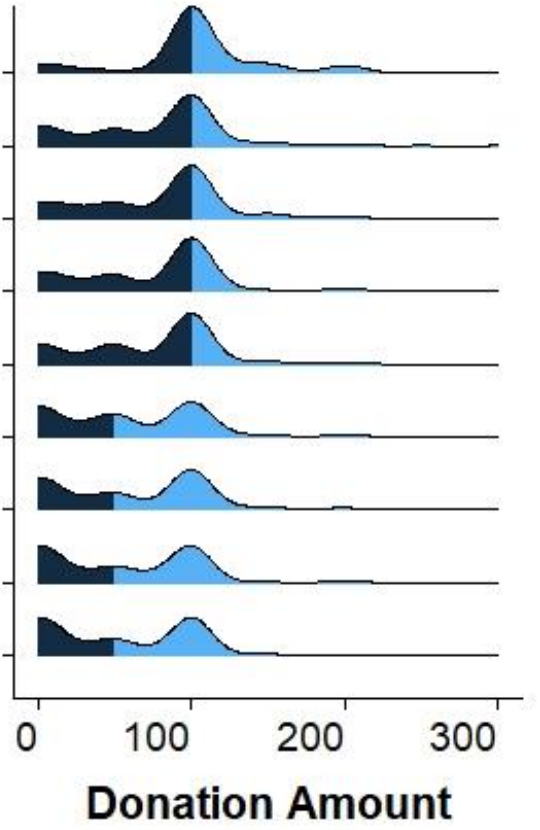




\section{Additional materials for Experiment 3}

\section{Sample size calculation for Experiment 3.}

As our dependent variable is continuous but not normally distributed, we based the power analysis on a categorical recoding of our dependent variable, in combination with information about the distribution of the dependent variable in Experiments 1 and 2. In doing so, we aim to approximate a distribution change, not only with respect to mean value, but also with respect to different distribution shape (We refer to Figures 5 and 6 in the Online Appendix). We first recoded donation amounts into four categories: (1) 'donation amount is 0', (2) 'donation amount is larger than 0 but smaller than 100', (3) 'donation amount is exactly 100' (this means respondents decided not to change their donation as a result of the information they received), and (4) 'donation amount is larger than 100'. For example, for Group 1 in the first experiment, which are the respondents who just received a description of the organization. Eight of 58 respondents reduced their donation to $0(13.8 \%), 8$ reduced their donation to an amount between 0 and $100(13.8 \%), 33$ did not change their donation and gave again $100 \$$ (56.9\%), and 9 increased their donation (15.5\%). We can consider this as the distribution of donations that the organization would have received in cases where no fraud occurred. However, when we compare this with the distribution of Group 2, i.e. with the description of the organization and the fraud event, we see a change in this distribution towards 20 (32.8\%), $13(21.3 \%), 26(42.6 \%)$, and 2 $(3.28 \%)$ respondents for the respective categories. Hence, the change in probability distribution, which can be considered an approximation of the negative effect induced by the crisis (regardless how it was communicated) is associated with an effect of $\mathrm{w}=0.801$ for a chi-square based power analysis (Champely 2018, based on Cohen 1988). Second, a power calculation indicates that we needed at least 12 observations per cell to be able to find an effect of at least the full size of the severe crisis when comparing two groups in our experiment with each other (power at 0.8 and significance at 0.01; We used 0.01 for our power analysis to compensate for multiple comparisons when interpreting our final results at 0.05$)$. Hence, in order to detect a mitigating effect of voluntary disclosure that completely counters the negative effect of the severe crisis information this is the minimal cell size required. However, to be able to detect a mitigating effect that can reduce the negative effect of a large crisis (Experiment 1) by, for example, 30 percent $(0.801 * 0.3)$ we would need at least 134 respondents per cell. With 250 respondents per cell we could uncover a mitigating effect of less than 25 percent of a severe crisis ( $\mathrm{w}=0.1758 ; 22.96$ percent), if such an effect exists. Even larger samples would enable us to find smaller proportions of mitigation, but we decided that a 20-25 percent (or greater) reduction in the donation loss following an organizational scandal would be practically significant, while finding 
a smaller effect size would be less so. For example, based on findings from Experiment 1, if an organization lost approximately 40 percent of prior year donations following a severe fraud event, with 250 respondents per cell, we would be able to identify a mitigation effect that reduced the drop in donations to around a 30 percent loss, or less. Similarly, the associated effect for change in distribution for the less severe crisis (Experiment 2) is w $=0.441$, for which at least 40 observations per cell would be necessary to detect in Experiment 3. With 250 respondents per cell we would be able to identify a mitigating effect that reduces the smaller crisis situation from Experiment 2 by at least 40 percent, or for instance a reduction of the expected loss from around a $\$ 20$ loss per respondent to around a $\$ 12$ or less loss per respondent. As a matter of comparison, a power analysis for an ANOVA test with five or four groups shows that with 250 observations per cell, respectively an effect size of $f=0.0979$ or $f$ $=-0.1046$ (significance $=0.05$, Power $=0.80)$. This is categorized as a 'small' effect $(\mathrm{f} \approx 0.10$; Champely 2018, based on Cohen 1988).

\section{Complementary analyses}

Greater data collected in Experiment 3 allowed us to perform additional complementary analyses in addition to the replication discussed in the main body of the article.

Based on Fayant et al. (2017) we applied a single and overall memory check questions for all respondents for the overall crisis description. As the information of disclosure type was embedded in this description, we assume that this overall question is a useful test to evaluate whether respondents have read the vignette. In addition, we added a second memory check question that tested whether respondents could remember the exact formulation of disclosure type. This gives us an insight in the proportion of respondents that were more actively paying attention to disclosure type. A substantial part of the of the 2,098 respondents (groups 2 to 9) that did get explicit information on disclosure, did indeed remember the exact formulation correctly $(60.68 \%)$, and another part only remembered it partially correctly $(18.30 \%$; e.g. indicating 'voluntary disclosure' when they got in fact 'both voluntarily and third-party disclosure'. When we apply these criteria in a strict way, i.e. we conduct an additional sensitivity analysis with only the 1,566 respondents that could remember the exact formulation out of four options, findings are consistent with those we report in the main text. We still do not find support for our hypothesis, which expected significant differences in donation amounts between groups that were presented voluntary disclosure information versus those that were not. For the less severe crisis, Kruskal-Wallis chi-squared $=2.8538, \mathrm{df}=3$, p-value $=0.4147$; and for the severe crisis, Kruskal-Wallis chi-squared $=3.0482, \mathrm{df}=3, \mathrm{p}$-value $=0.3843$. Because of the lower $\mathrm{N}$, however, it should be noted 
that due to the smaller cell sizes (smallest cell size is 122) only a mitigation effect of around 30\% or greater of a large crisis could be precisely estimated. Nevertheless, as discussed in our notes, smaller expected reductions are less practically significant. Based on our findings and power analysis, we can say that in reality there is either no true effect of voluntary disclosure information on stakeholder donation decisions or that information on voluntary disclosure potentially reduces the negative impact of nonprofit scandals only to a limited extent.

\section{Figure 7}

Geographical distribution of respondents in Experiment 3; Approximated location based on IP address

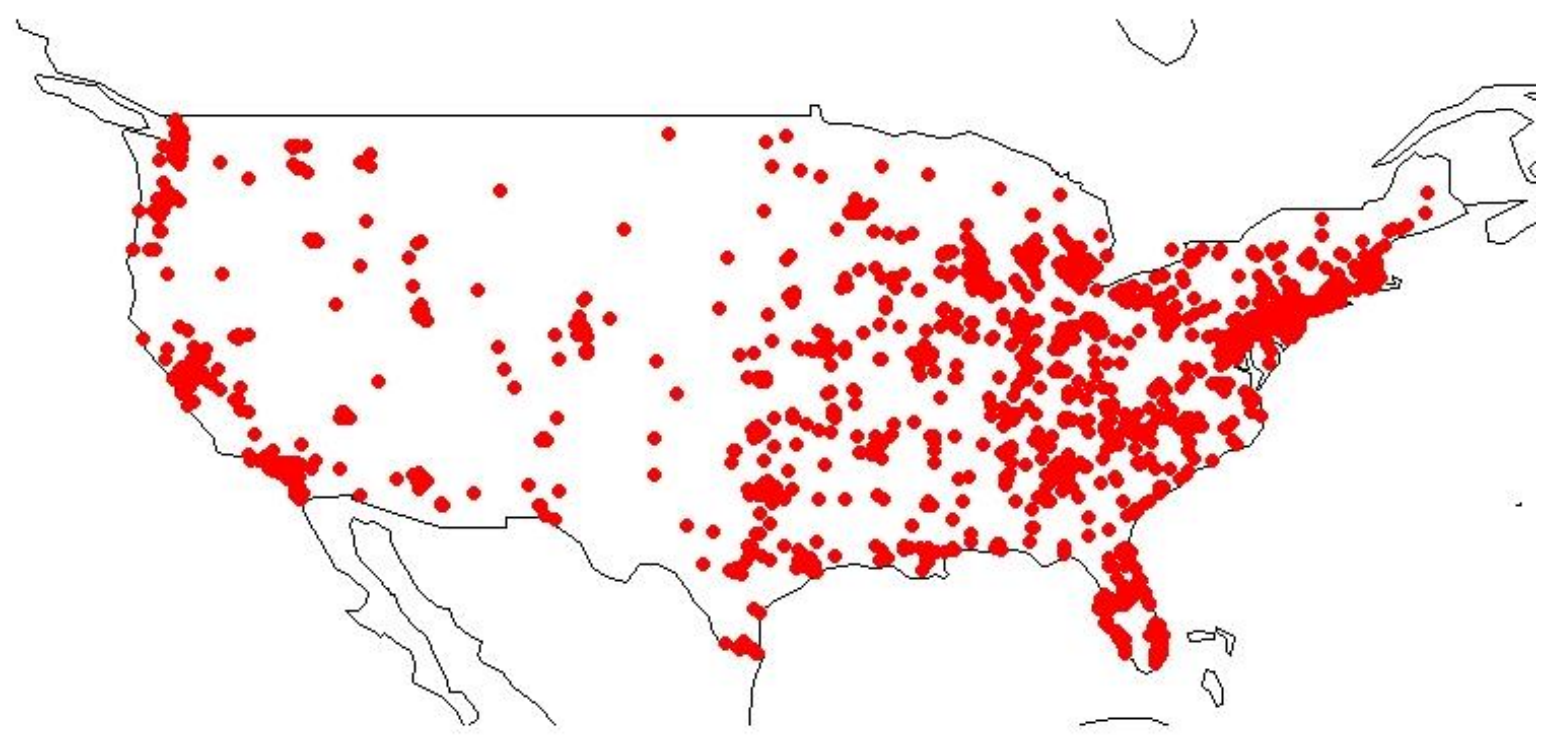

\section{Table 8}

Items to measure organizational trustworthiness (Tax, Brown \& Chandrashekaran, 1998; Willems, Jegers, \& Faulk, 2016), and factor loadings

\begin{tabular}{llc}
\hline \hline & Items (from Tax, Brown \& Chandrashekaran, 1998) & Loading \\
\hline Trust_1 & I believe EarthLove could not be relied upon to keep its promises. (R) & -0.688 \\
Trust_2 & I believe EarthLove is trustworthy. & 0.941 \\
Trust_3 & I would find it necessary to be cautious in dealing with EarthLove. (R) & -0.673 \\
Trust_4 & Overall, I believe EarthLove is honest. & 0.911 \\
\hline
\end{tabular}

The question asked was: How would you judge the trustworthiness of Earthlove? Please indicate to what extent you agree with the following statements.

Answer options were: Strongly Disagree (-3); Disagree (-2); Somewhat Disagree (-1); Neither Agree nor Disagree (0); Somewhat Agree (1); Agree (2); Strongly Agree (3)

The order of the four items was randomized for each respondent.

Cronbach's alpha $=0.8781$ 
Figure 7 gives an indication of the geographical spread of the respondents in Experiment 3. However, we acknowledge that this is just an approximation as we rely on derived location from IP addresses. Table 8 shows the items and factor loadings for the complementary trust variable in Experiment 3.

Figure 8 gives the proportions per treatment group for donation categories. This graph shows proportions per treatment group that decided to repeat their prior 100 dollar donation (black), or change to another donation category (variations of red). Hence, it can be visually derived how much the treatments changed donation decisions, including the decision to stop donating.

\section{Figure 8}

Histograms per treatment group, indicating proportions that donated $\$ 100$ (the psychological anchor) (black), or changed their donation amount (variations of red).

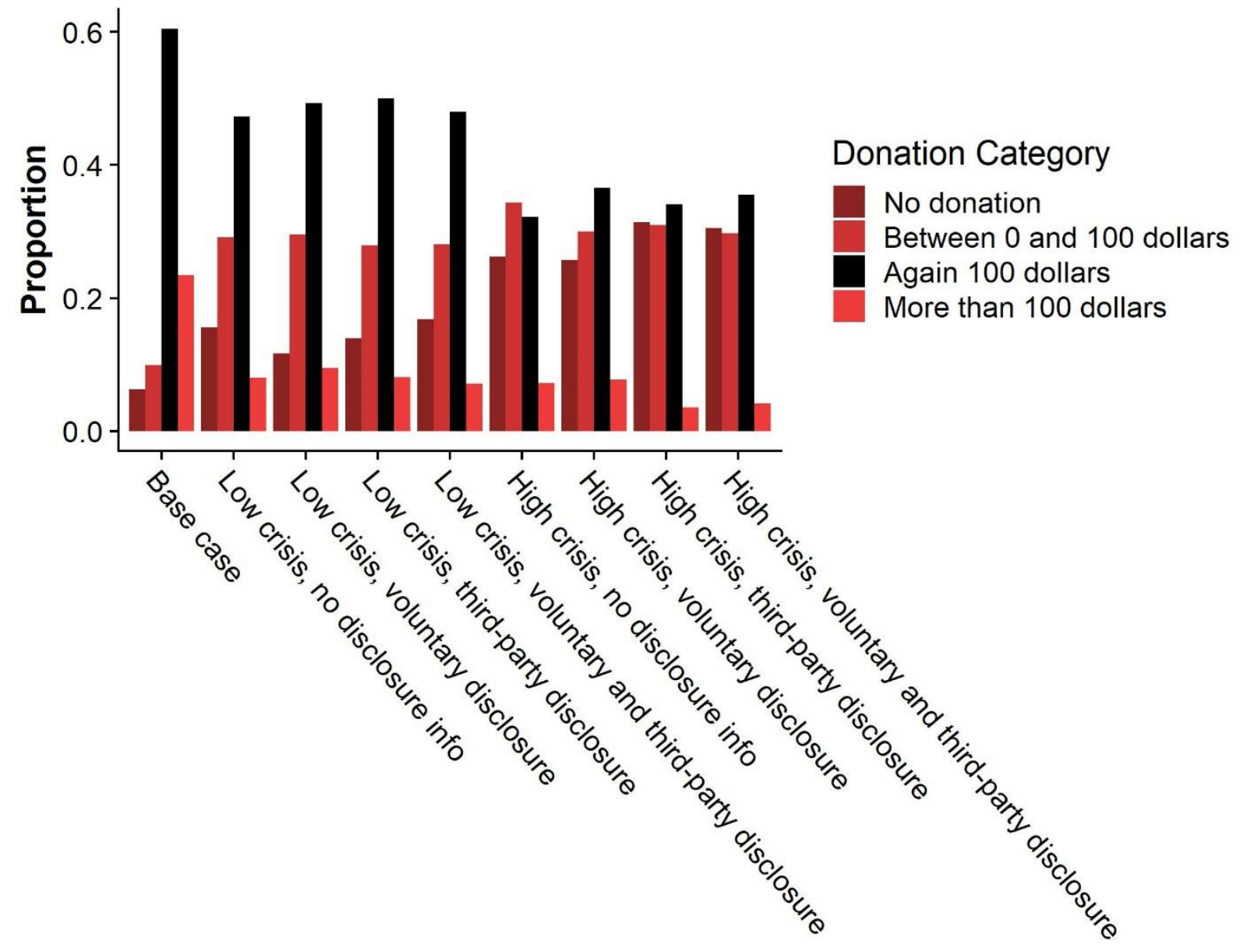

Treatment category 


\section{References}

Champely, S. (2018). pwr: Basic functions for power analysis. R package version 1.2-2. https://CRAN.R-project.org/package=pwr

Cohen, J. (1988). Statistical Power Analysis for the Behavioral Sciences (2nd ed.). Hillsdale,NJ: Lawrence Erlbaum.

Fayant, M., Sigall, H., Lemonnier, A., Retsin, E., \& Alexopoulos, T. (2017). On the limitations of manipulation checks: An obstacle toward cumulative science. International Review of Social Psychology, 30(1), 125-130.

R Core Team (2018). R: A language and environment for statistical computing. https://www.Rproject.org/

Tax, S. S., Brown, S. W., \& Chandrashekaran, M. (1998). Customer evaluations of service complaint experiences: Implications for relationship marketing. Journal of Marketing, 62(2), 60-76.

Willems, J., \& Faulk, L. (2019) (a). Does voluntary disclosure matter when nonprofit organizations violate stakeholder trust? Journal of Behavioral Public Administration, 2(1). http:/ /journalbpa.org/index.php/jbpa/article/view/45

Willems, J., \& Faulk, L. (2019, February 13) (b). Does voluntary disclosure matter when nonprofit organizations violate stakeholder trust? - Additional materials. Open Science Foundation. Retrieved from https://osf.io/wqzsa

Willems, J., Jegers, M., \& Faulk, L. (2016). Organizational effectiveness reputation in the nonprofit sector. Public Performance and Management Review, 39(2), 476-497.

Willems, J., \& Waldner, C. J. (2019). Reputation Management for Nonprofit Organizations. Retrieved from Open Science Foundation: https://osf.io/wj2ep ; DOI: 10.31219/osf.io/wj2ep 